University of Nebraska - Lincoln

DigitalCommons@University of Nebraska - Lincoln

U.S. National Park Service Publications and

Papers

National Park Service

2018

Influence of Invasive Hybrid Cattails on Habitat Use by Common

Loons

Spencer L. Wesche

Benjamin J. O'Neal

Steve K. Windels

Bryce T. Olson

Max Larreur

See next page for additional authors

Follow this and additional works at: https://digitalcommons.unl.edu/natlpark

This Article is brought to you for free and open access by the National Park Service at DigitalCommons@University of Nebraska - Lincoln. It has been accepted for inclusion in U.S. National Park Service Publications and Papers by an authorized administrator of DigitalCommons@University of Nebraska - Lincoln. 
Authors

Spencer L. Wesche, Benjamin J. O'Neal, Steve K. Windels, Bryce T. Olson, Max Larreur, and Adam A. Ahlers 
From The Field

\title{
Influence of Invasive Hybrid Cattails on Habitat Use by Common Loons
}

\author{
SPENCER L. WESCHE, Department of Biology, Franklin College, Franklin, IN 46131, USA \\ BENJAMIN J. O'NEAL, Department of Biology, Franklin College, Franklin, IN 46131, USA \\ STEVE K. WINDELS, National Park Service, Voyageurs National Park, International Falls, MN 56649, USA \\ BRYCE T. OLSON, National Park Service, Voyageurs National Park, International Falls, MN 56649, USA \\ MAX LARREUR, Department of Horticulture and Natural Resources, Kansas State University, Manhattan, KS 66506, USA \\ ADAM A. AHLERS, ${ }^{1}$ Department of Horticulture and Natural Resources, Kansas State University, Manhattan, KS 66506, USA
}

\begin{abstract}
An invasive hybrid cattail species, Typha $\times$ glauca $(T . \times$ glauca $)$, is rapidly expanding across the United States and Canada. Dense clonal stands of $T . \times$ glauca outcompete native wetland plants, reduce open-water habitats, and negatively affect native wetland plant diversity; however, effects of hybrid cattail expansions on native wildlife are still unclear. We used multiple surveys and single-season occupancy models to examine how the relative coverage of $T$. $\times$ glauca affected habitat use by common loons (Gavia immer) at 71 wetland sites in Voyageurs National Park, Minnesota, USA, during summer 2016. Delineated wetland sites ( $2 \mathrm{ha}$ ) were considered potential resource patches for common loons and positioned along a gradient of relative $T . \times$ glauca coverage. Detection of common loons was influenced negatively by the time of day surveys were conducted. Occupancy probabilities were greater at sites with deeper water levels, possibly indicating selection for areas with adequate water depths for pursuit-based foraging for fish. Contrary to our hypothesis, common loons appeared insensitive to the relative coverage of $T . \times$ glauca at wetland sites. Future research should focus on elucidating potential threshold-effects of $T . \times$ glauca expansions on additional loon demographic rates. (c) 2018 The Wildlife Society.
\end{abstract}

KEY WORDS cattails, common loon, Gavia immer, invasive species, T. $\times$ glauca, Voyageurs National Park, waterbird, wetland management.

Typha $\times$ glauca (hereafter, “T. $\times$ glauca”), a successful hybrid between native broad-leaf cattail (Typha latifolia) and invasive narrow-leaf cattail (Typha angustifolia), is considered the most invasive Typha species in North America (Travis et al. 2010, Larkin et al. 2011, Marburger and Travis 2013). Once established, $T . \times$ glauca rapidly dominates native vegetation communities by outcompeting native plants for light and nutrient resources because of its physical structure and extensive root system (Travis et al. 2010, 2011). $T$. $\times$ glauca's rapid replacement of native vegetation results in dense monoculture stands that can negatively affect wetland plant diversity (Tuchman et al. 2009, Travis et al. 2010, Larkin et al. 2011, Marburger and Travis 2013). Although effects of $T . \times$ glauca's encroachment on native plants and wetland structure have been well-established, less is known of its possible effects on native wildlife (Tuchman et al. 2009, Travis et al. 2010, Larkin et al. 2011, Marburger and Travis 2013).

Received: 22 June 2017; Accepted: 29 December 2017

Published: 13 March 2018

${ }^{1}$ E-mail: aahlers2@ksu.edu
Common loon (Gavia immer; henceforth, "loons") is a large piscivorous waterbird (3.2-5.2 kg) and an iconic species in boreal lakes and lacustrine wetlands where $T . \times$ glauca is rapidly establishing (Piper et al. 1999, Windels et al. 2013). Loons are important predators in aquatic food webs and rely on high-quality habitats to forage and reproduce (Piper et al. 1999, McCarthy and DeStefano 2010, Radomski et al. 2014). The littoral zone serves as vital foraging areas for loons as they hunt for yellow perch (Perca flavescens), pumpkinseed (Lepomis gibbosus), and bluegill (Lepomis macrochirus; Strong and Bissonette 1989, Ruggles 1994, Evers 2007). Prey-rich waters are critical for obtaining necessary caloric input, which can be in excess of $423 \mathrm{~kg}$ of fish for a loon family (2 adults, 2 chicks) in a single breeding season (Barr 1996, Evers 2007). These areas can provide loons with an abundance of prey and sufficient foraging areas for pursuit of highly mobile and erratic prey (Strong and Bissonette 1989, Ruggles 1994, Barr 1996, Evers 2007).

It is plausible that expanding $T$. $\times$ glauca populations could negatively affect habitat quality for common loons; however, this hypothesis has not yet been evaluated. Although $T . \times$ glauca reduces open-water area in wetlands, potentially reducing loon foraging areas, loons often construct floating nests made of emergent vegetation, including cattail litter, 
which suggests a potential positive effect of abundant T. $\times$ glauca stands (Mathieson 1969, DeSorbo et al. 2006, Windels et al. 2013). Thus, the relationship between loons and $T . \times$ glauca remains unclear.

Our goal was to quantify effects of $T$. $\times$ glauca encroachment on habitat use by loons in a representative lake ecosystem. If expanding $T . \times$ glauca populations limit the spatial distribution of loons, we expected lower habitat occupancy rates at sites with abundant $T$. $\times$ glauca coverage. We also predicted site occupancy probabilities by loons would be greater in deeper water and reduced submergent vegetation because these areas likely provide better foraging opportunities.

\section{STUDY AREA}

Our study was focused in Rainy and Kabetogama lakes in northern Minnesota, USA $\left(48.6026^{\circ} \mathrm{N},-93.40365^{\circ} \mathrm{E}\right.$; Fig. 1). Both lakes were located on the United StatesCanada border with portions of each falling within the boundaries of Voyageurs National Park (VNP; 88,300 ha; Fig. 1). Our study area occurred in the boreal ecosystem characterized by warm, humid summers $\left(\bar{x}\right.$ temp $\left.=17^{\circ} \mathrm{C}\right)$ and cold, dry winters $\left(\bar{x}\right.$ temp $\left.=-13^{\circ} \mathrm{C}\right)$ with a mean annual precipitation level of $62 \mathrm{~cm}$ (Kallemeyn et al. 2003, NOAA 2016). Shorelines and littoral zones of both lakes were dominated by mats of $T$. $\times$ glauca with small patches of common water reed (Phragmites australis), wild rice (Zizania spp.), and bulrush (Schohenoplectus acutus) dispersed throughout (Kallemeyn et al. 2003, Windels et al. 2013). Both lakes contained hundreds of small islands and wetlands that serve as potential nesting habitat for waterbird species including loons (Windels et al. 2013; Fig. 1). Dams at the outlets of both lakes maintained dynamic water levels, with annual peak water levels in Rainy Lake and Kabetogama Lake around 1 June and 1 July, respectively (Kallemeyn et al. 1993, Windels et al. 2013). Native broad-leaf cattails were extremely rare in VNP and recent research suggested

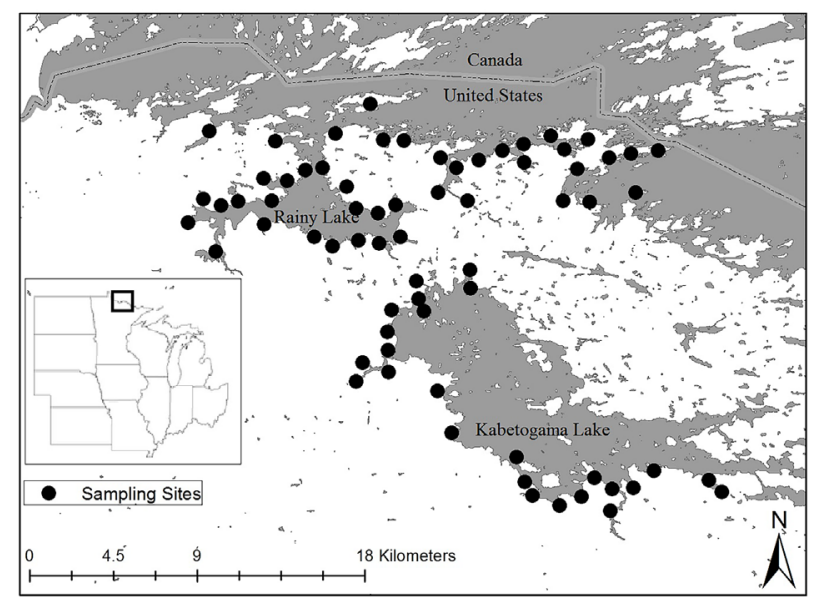

Figure 1. Sampling sites (dark circles; $n=71$ ) used to assess common loon habitat occupancy in wetlands in Voyageurs National Park, Minnesota, USA. Each randomly selected site ( $2 \mathrm{ha}$ ) was considered a resource patch and sampled 3 times during the summer of 2016 for the presence or absence of common loons.
T. $\times$ glauca was the dominant cattail species in the region (Travis et al. 2010, Marburger and Travis 2013).

\section{METHODS}

\section{Data Collection}

We sampled 71 sites within Rainy and Kabetogama lakes to assess the presence or absence of loons. We used a digital vegetation map of VNP (based on the National Vegetation Classification System; Faber-Langendoen et al. 2007) to identify all wetlands adjacent to Rainy and Kabetogama lakes and delineated these areas as unique polygons in ArcMap 10.4 (ESRI 2015). We randomly selected unique polygons to sample and ground-truthed each to ensure they occurred in wetland habitats. We then established our sampling sites on the general centroid of each randomly selected wetland polygon $(n=71 ;$ Fig. 2$)$. Sites were separated by a mean Euclidian distance of $1,247 \mathrm{~m}$ $(\mathrm{SD}=377 \mathrm{~m})$ and a post hoc analysis determined that sites were distributed across a gradient of $T . \times$ glauca coverage (Fig. 3). We considered each site a resource patch (2 ha) because it was much smaller than the average loon home range (6-200 ha; Evers et al. 2010).

We determined loon occupancy at each site by repeated visual surveys conducted by 2 observers from 1 June 2016 to 6 August 2016. All surveys were conducted between 0700 and 1800. Observers accessed sites by a single motorized boat, stopped approximately $100 \mathrm{~m}$ from the centroid of each site, and visually searched for loons for 5 min using binoculars. If a loon was detected within the boundaries of our site by $\geq 1$ observer during a site visit, the site was determined to be occupied. We conducted 3 visits to each site (i.e., one survey per visit) and separated each site visit by $\leq 1$ week to ensure population closure (MacKenzie et al. 2006). Thus, our detection histories for each site included 3 primary sampling periods. Our total sampling effort included 213 independent surveys across 142 ha of wetland habitat.

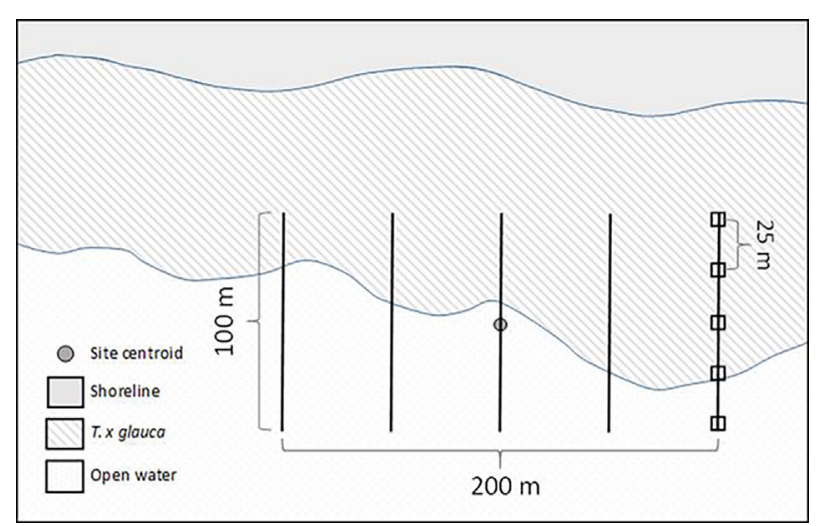

Figure 2. Schematic diagram of a wetland site used to assess common loon habitat occupancy and measure site-level habitat variables in Voyageurs National Park, Minnesota, USA, during 2016. Vertical lines represent common loon habitat sampling transects. Small boxes positioned on the right transect show habitat sampling points along each transect. Patterns represent the location of upland shoreline, extent of Typha $\times$ glauca encroachment, and open water. 


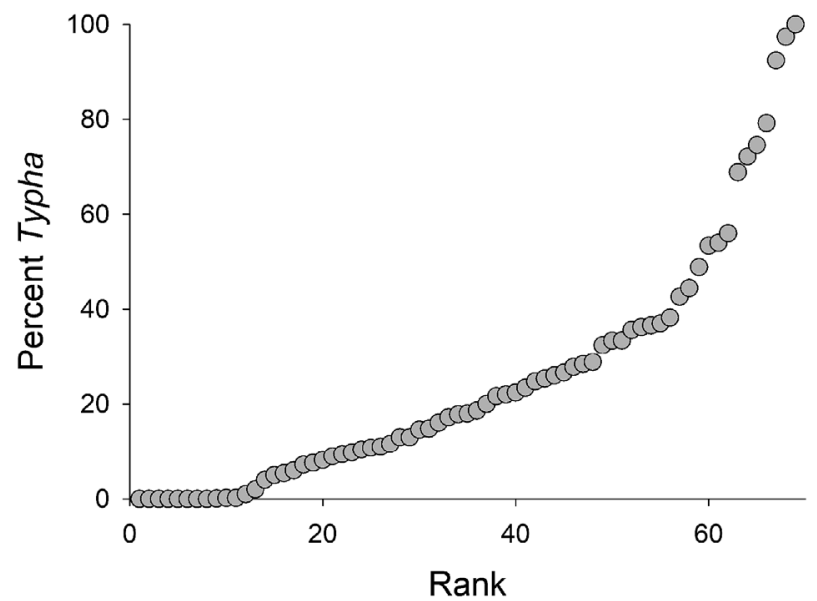

Figure 3. Distribution of wetland sites $(n=71)$ sampled for common loon occupancy in Minnesota, USA, during the summer of 2016, ranked by percent of $T \times$ glauca coverage at each site.

We measured several survey-specific variables that could potentially affect our ability to detect loons. We expected greater loon detection probabilities on days with greater relative ambient air temperatures, low wind speeds, clear skies, and no precipitation. We measured temperature $\left({ }^{\circ} \mathrm{C}\right)$, wind speed $(\mathrm{km} / \mathrm{hr})$, and direction using a hand-held device (Kestrel ${ }^{\mathbb{R}}$ 2500, Nielsen-Kellerman, Boothwyn, PA, USA). We quantified cloud cover as the percentage of sky that appeared cloudy and segregated these percentages into tenths $(1=$ no clouds, $10=$ completely cloudy $)$. We measured and recorded precipitation during the survey on a scale from 0 to $3(0=$ no precipitation, $3=$ heavy precipitation).

We established 5 parallel transects $(100 \mathrm{~m}$ long, each separated by $50 \mathrm{~m}$ ), centered on the centroid of each site, to measure site-specific habitat variables that could be important for habitat selection by loons (Fig. 2). Transects were positioned perpendicular to the shoreline (Fig. 2). At 5 evenly spaced positions along each transect, we used a $1-\mathrm{m} \times 1-\mathrm{m}$ floating Daubenmire frame to estimate the percentage of $T$. $\times$ glauca coverage, percentage of open-water habitat, water depth $(\mathrm{m})$, maximum vegetation height $(\mathrm{m})$, substrate type (rocky, muddy, rocky-muddy, muddy-rocky), and coverage of other species-specific native plants (i.e., rushes, sedges, grasses). We calculated a mean for these measurements $(n=25)$ for each site to obtain a single sitelevel estimate for individual habitat covariates.

\section{Data Analysis}

We developed single-season occupancy models to assess the relative influence of our measured covariates on local-scale habitat occupancy by loons (Program PRESENCE 11.3; MacKenzie et al. 2006). Our candidate set of detection models $(n=8)$ included the single and additive effects of our survey-specific detection covariates along with a constant model. For our occupancy rate parameter, we considered a candidate set of models that included the single and additive combinations of all possible covariate combinations along with the intercept-only model $(n=27)$. Additionally, we included 5 models that investigated support for a potential interaction between water depth and our measured site vegetation characteristics. We did not include covariates that were correlated $(|r| \geq 0.50)$ within the same model. We assessed support for each model using Akaike's Information Criterion corrected for small sample sizes $\left(\mathrm{AIC}_{c}\right)$ and we evaluated the importance of each variable's inclusion in competitive models $\left(\Delta \mathrm{AIC}_{c} \leq 2.00\right)$ using an information theoretic approach (Burnham and Anderson 2002, Arnold 2010). We first selected the model that best explained loon detection and then subsequently fit single-season occupancy models that also incorporated our most-supported detection model (Ahlers et al. 2016).

\section{RESULTS}

We observed loons at 39 of 71 sites (naïve occupancy $=0.55$ ). Based on our constant model of detection and occupancy, per-survey detection probabilities for loons was moderate $(\rho=0.49, \mathrm{SE}=0.06)$ and corrected site occupancy was 0.63 $(\mathrm{SE}=0.08)$. Our top model of detection indicated that the time of day surveys were conducted (Time) influenced our ability to detect loons (Table 1). Detection probabilities for loons decreased later in the day (Time; $\beta=-0.0015$, $\mathrm{SE}=0.0003$; Table 1). Covariates "Wind" and "Day of the year" were also present in competitive models; however, based on the minimal change in model fit, it was likely they were uninformative parameters (Burnham and Anderson 2002, Arnold 2010). Thus, we used our "Time" detection model to fit subsequent single-season occupancy models.

Our most-supported model of loon occupancy included the single effect of water depth, suggesting occupancy probabilities were greater at sites with deeper water (Depth; $\beta=4.89$, $\mathrm{SE}=1.80$; Table 1; Fig. 4). Additionally, models that incorporated the covariate "Depth" contributed to the majority of all model weights $\left(\Sigma w_{\text {Depth }}=0.95\right.$; Table 1$)$. There were 4 other competitive models; however, none explained these data substantially better than our top-ranked model (differences in deviance values from all competitive models relative to the top model $=0.22-0.66$; Table 1 ). Our other covariates, including "Typha," were likely benefitting by the effect of "Depth" (difference in deviance value of the "Depth + Typha" model from top model $=0.31$; Table 1; Fig. 5) and were uninformative (Burnham and Anderson 2002, Arnold 2010). There was no support for models that included interactions between water depths and other measures of vegetation cover (Table 1).

\section{DISCUSSION}

Expansion of invasive hybrid cattail populations into North American wetlands is an immediate concern for land and wildlife managers. This novel landscape change necessitates information on species-specific sensitivities to encroaching nonnative vegetation. We found that our ability to detect loons in regions where $T . \times$ glauca is expanding is influenced by the time of day the survey was conducted. Our results also indicate that habitat use by loons is influenced more by water depth than encroachment by $T . \times$ glauca, suggesting that loon distributions are relatively insensitive to expanding $T . \times$ glauca populations at the local scale. 
Table 1. Competitive models that explain variation in detection and habitat occupancy by common loons in northern Minnesota, USA, in 2016. We ranked models by descending $\Delta \mathrm{AIC}_{c}$. $w=$ model weight; $K=$ number of estimable parameters in each model; Deviance $=-2$ (Log Likelihood). Parameters in each model include: Time (time of day), DOY (day of the year), Wind (average wind speed), Depth (average water depth), Emerg (\% emergent vegetation coverage), WoodyVeg (\% woody vegetation coverage), Typha (\% $T$. $\times$ glauca coverage), VegHeight (average vegetation height), SubVeg (\% submergent vegetation cover), and Intercept only (model intercept). We only present models within $\Sigma w \geq 0.95$ for each rate parameter along with the Intercept only model.

\begin{tabular}{|c|c|c|c|c|}
\hline Model & $\Delta \mathrm{AIC}_{c}$ & $w$ & $K$ & -2 Log Likelihood \\
\hline \multicolumn{5}{|l|}{ Detection } \\
\hline Time & 0.00 & 0.40 & 3 & 243.77 \\
\hline Time + DOY & 1.22 & 0.22 & 4 & 242.99 \\
\hline Time + Wind & 1.96 & 0.15 & 4 & 243.73 \\
\hline Time + DOY + Wind & 3.12 & 0.08 & 5 & 242.89 \\
\hline Intercept only & 3.71 & 0.06 & 2 & 249.48 \\
\hline Wind & 4.71 & 0.03 & 3 & 248.48 \\
\hline \multicolumn{5}{|l|}{ Occupancy } \\
\hline Depth & 0.00 & 0.23 & 4 & 229.27 \\
\hline Depth + Emerg & 1.34 & 0.12 & 5 & 228.61 \\
\hline Depth + Typha & 1.69 & 0.10 & 5 & 228.96 \\
\hline Depth + WoodyVeg & 1.73 & 0.10 & 5 & 229.00 \\
\hline Depth + SubVeg & 1.78 & 0.10 & 5 & 229.05 \\
\hline Depth + SubVeg + Depth $\times$ SubVeg & 3.08 & 0.09 & 6 & 228.35 \\
\hline Depth + WoodyVeg + Depth $\times$ WoodyVeg & 6.71 & 0.05 & 6 & 232.77 \\
\hline Depth + Emerg + Depth $\times$ Emerg & 6.82 & 0.05 & 6 & 232.88 \\
\hline Depth + VegHeight + Depth $\times$ VegHeight & 7.26 & 0.05 & 6 & 233.32 \\
\hline Depth + Typha + Depth $\times$ Typha & 8.06 & 0.04 & 6 & 236.12 \\
\hline Open Water + Typha & 9.59 & 0.04 & 5 & 235.65 \\
\hline Intercept only & 12.50 & 0.00 & 3 & 243.77 \\
\hline
\end{tabular}

Our most-supported detection model suggests that loons were more apparent to observers earlier in the day. During the summer, adult loon activity varies according to their breeding and nesting habits (Nocera and Taylor 2000). Visible adult loon activity peaks prior to nesting as they consistently forage, but diminishes later in the summer as they dedicate most of their time to nest-sitting and, beginning posthatch, to resting and chick-rearing (Evers 1994). As expected, we detected loons more frequently earlier in the day because loons actively forage during this

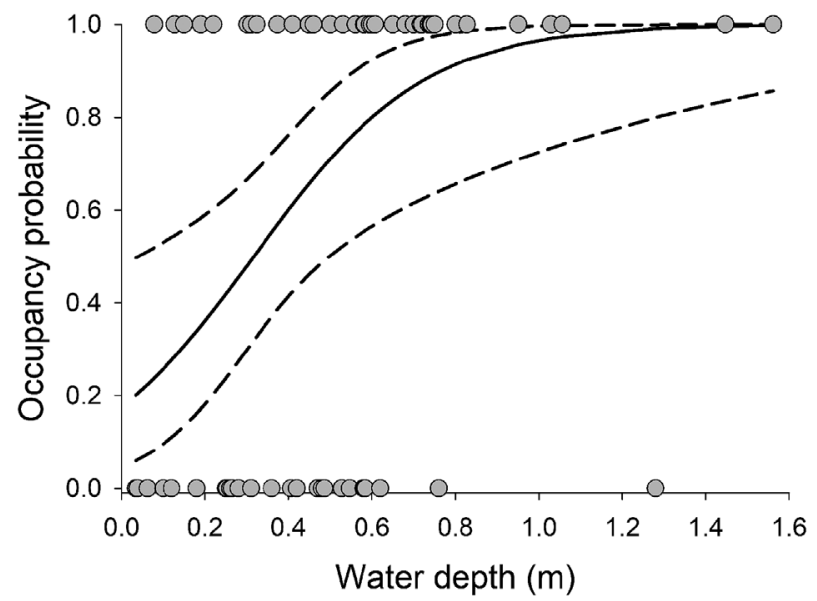

Figure 4. The relationship between water depth (m) and habitat occupancy probabilities by common loon at wetland sites $(n=71)$ in Minnesota, USA, during the summer of 2016. Occupancy estimates (solid line) and 95\% confidence intervals (dashed line) were derived from our top-ranked singleseason occupancy model (Table 1). Gray circles indicate naïve site occupancy ( $1=$ occupied, $0=$ absent $)$ of common loons at sites with varying water depths. time and are most vocally active from late evening to early morning (Evers et al. 2010, Mennill 2014).

We found a positive relationship between habitat occupancy by loons and water depth. The likelihood of a site being occupied by loons was greater at sites with deeper water. Within $T . \times$ glauca dominated sites (i.e., sites with $>50 \% \quad$ T. $\times$ glauca coverage), open-water habitat was generally $\leq 0.4 \mathrm{~m}$ deep, which may inhibit loons' foraging behavior (peering underwater, locating prey then diving in pursuit; McIntyre 1988, Banner and Schaller 2001). We

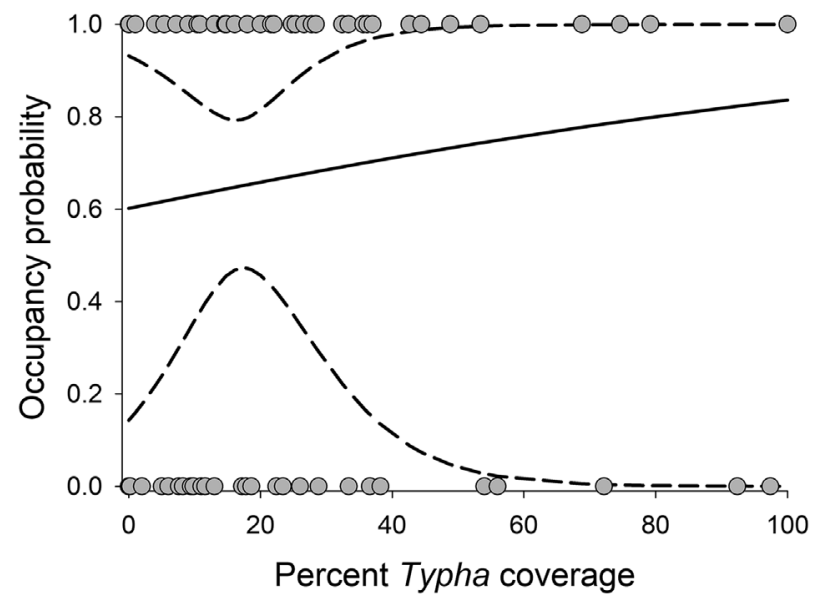

Figure 5. The relationship between percent Typha $\times$ glauca coverage and habitat occupancy probabilities by common loon at wetland sites $(n=71)$ in Minnesota, USA, during summer 2016. Occupancy estimates (solid line) and $95 \%$ confidence intervals (dashed line) were derived from a competitive single-season model (Depth + Typha; Table 1) while holding the covariate "Depth" constant at its median value. Gray circles indicate naive site occupancy ( $1=$ occupied, $0=$ absent $)$ of common loons along a gradient of Typha $\times$ glauca coverage (0-100\%) of each site. 
speculate that these shallow sites were less occupied because they lacked adequate depth to support pursuit-based foraging, which is important for successful summer survival and reproduction (Gadomski and Parsley 2005, Thompson and Price 2006).

Contrary to our hypothesis, loons did not avoid sites that were exposed to $T . \times$ glauca encroachment. The absence of a negative $T . \times$ glauca effect could be a result of an indirect positive effect related to the abundance of cattail litter or floating cattail mats useful for construction of nesting platforms (Mathieson 1969). Indeed, the probability of loon nest success is greater for nests that are positioned on floating mats or artificial floating platforms than those on shore (Mathieson 1969, Vermeer 1973, Windels et al. 2013). This effect is particularly relevant at VNP, which is marked by a dynamic hydrology brought on by active management for both hydropower and flood control (Windels et al. 2013). Abundant floating $T . \times$ glauca mats may mediate negative impacts of water-level changes by offering nesting substrate that can accommodate modest changes in water levels (Reiser 1988, Kallemeyn et al. 1993, Windels et al. 2013). It is possible that lakes with less dynamic hydrology regimes may experience differing relationships between $T . \times$ glauca coverage and loon distribution. Future research should focus on the potential interaction between human-modified hydrology and presence of $T . \times$ glauca on wetland-obligate species (e.g., waterbirds, semiaquatic mammals, amphibians).

Although our study suggests loons are tolerant of expanding $T . \times$ glauca populations, we acknowledge 2 caveats that may affect our interpretation of the results. First, because our study was limited to a local resource patch-use scale $(2 \mathrm{ha})$ and single season and year (summer 2016), it may not reveal patterns occurring at larger spatiotemporal scales. However, our study does provide a snapshot of patterns likely emerging during a critical life history stage for loons. Second, aggressive expansions of $T . \times$ glauca results in dense monocultures in exposed wetlands. Under some conditions, loons could experience a threshold-related response in which occupancy and other vital rates may become negatively affected by extreme levels of cattail coverage (i.e., 90-100\%). Our sampled wetland sites included few wetlands that were completely dominated by $T . \times$ glauca, so we may have been unable to detect this effect. Future studies should work to uncover potential thresholds of $T . \times$ glauca coverage on demographic rates of loons.

Voyageurs National Park has recently started a management program to treat $T . \times$ glauca-invaded wetlands in the park's large lakes. Our results suggest that targeted removal of $T$. $\times$ glauca in wetlands may promote increases in the amount of habitat with sufficient water depth to support loon foraging and result in an increase in overall available habitat for loons at VNP. Past research has documented that floating mats of $T . \times$ glauca are sometimes used as nesting structures by loons; therefore, park managers should consider leaving small patches of floating cattails in areas where loon production is often poor. We suggest basic and applied studies to investigate how T. $\times$ glauca removal techniques (e.g., cutting, dredging, burning) and intensity of removal patterns (e.g., complete eradication vs. leaving residual patches of cattails) affect demographic rates of loons and other wetland-obligate species.

\section{ACKNOWLEDGMENTS}

Our research was funded by the Department of Horticulture and Natural Resources at Kansas State University, Voyageurs National Park, the Branigin Engaged Learning Fund at Franklin College, and the Patterson Internship Fund. We thank the Associate Editor and anonymous reviewers for their comments and suggestions to this manuscript.

\section{LITERATURE CITED}

Ahlers, A. A., E. J. Heske, and R. L. Schooley. 2016. Prey distribution, potential landscape supplementation, and urbanization affect occupancy dynamics of American mink in streams. Landscape Ecology 31:1601-1613.

Arnold, T. W. 2010. Uninformative parameters and model selection using Akaike's Information Criterion. Journal of Wildlife Management 74:1175-1178.

Banner, A., and S. Schaller. 2001. U.S. Fish and Wildlife Service, Gulf of Maine Program, ME. Common loon habitat model. <https://www.fws. gov/r5gomp/gom/habitatstudy/metadata/common_loon_model.htm $>$. Accessed 13 Mar 2017.

Barr, J. F. 1996. Aspects of common loon (Gavia immer) feeding biology on its breeding ground. Hydrobiologia 321:119-144.

Burnham, K. P., and D. R. Anderson. 2002. Model selection and multimodel inference: a practical information-theoretic approach. Second edition. Springer-Verlag, New York, New York, USA.

DeSorbo, C. R., K. M. Taylor, D. E. Kramar, J. Fair, J. H. Cooley, Jr., D. C. Evers, W. Hanson, H. S. Vogel, and J. L. Atwood. 2006. Reproductive advantages for common loons using rafts. Journal of Wildlife Management 71:1206-1213.

ESRI. 2015. ArcGIS Desktop: Release 10.4. Environmental Systems Research Institute, Redlands, California, USA.

Evers, D. C. 1994. Activity budgets of a marked common loon (Gavia immer) nesting population. Hydrobiologia 279:415-420.

Evers, D. C. 2007. Status assessment and conservation plan for the common loon (Gavia immer) in North America: 2007. U.S. Fish and Wildlife Service, Hadley, Massachusetts, USA.

Evers, D. C., J. D. Paruk, J. W. McIntyre, and J. F. Barr. 2010. Common loon (Gavia immer). Account 313 in P. G. Rodewald, editor. The birds of North America. Cornell Lab of Ornithology, Ithaca, New York, USA. https://doi.org/10.2173/bna.313/ Accessed 20 Feb 2018.

Faber-Langendoen, D., N. Aaseng, K. Hop, M. Lew-Smith, and J. Drake. 2007. Vegetation classification, mapping, and monitoring at Voyageurs National Park, Minnesota: an application of the U.S. National Vegetation Classification. Applied Vegetation Science 10:361-374.

Gadomski, D. M., and M. J. Parsley. 2005. Effects of turbidity, light level, and cover on predation of white sturgeon larvae by prickly sculpins. Transactions of the American Fisheries Society 134:369-374.

Kallemeyn, L. W., Y. Cohen, and P. Radomski. 1993. Rehabilitation of the aquatic ecosystem of Rainy Lake and Namakan Reservoir by restoration of a more natural hydrologic regime. Pages 432-448 in L. W. Hesse, C. B. Stalnaker, N. G. Benson, and J. R. Zuboy, coordinators. Proceedings of the symposium on: restoration planning for the rivers of the Mississippi River ecosystem. National Biological Survey, Biological Report 19, Washington, D.C., USA.

Kallemeyn, L. W., K. L. Holmberg, J. A. Perry, and B. Y. Odde. 2003. Aquatic synthesis for Voyageurs National Park. U.S. Geological Survey Information and Technology Report, 2003-0001, Springfield, Virginia, USA.

Larkin, D. J., M. J. Freyman, S. C. Lishawa, P. Geddes, and N. C. Tuchman. 2011. Mechanisms of dominance by the invasive hybrid cattail Typha $\times$ glauca. Biological Invasions 14:65-77. 
MacKenzie, D. I., J. D. Nichols, J. A. Royle, K. H. Pollock, L. L. Bailey, and J. E. Hines. 2006. Occupancy estimation and modeling. First edition. Academic Press, Burlington, Massachusetts, USA.

Marburger, J., and S. Travis. 2013. Cattail hybridization in national parks: an example of cryptic plant invasions. Park Science 30:58-68.

Mathieson, J. E. 1969. Use of man-made islands as nesting sites of the common loon. Wilson Bulletin 81:331.

McCarthy, K. P., and S. DeStefano. 2010. Effects of spatial disturbance on common loon nest site selection and territory success. Journal of Wildlife Management 75:289-296.

McIntyre, J. W. 1988. The common loon: spirit of northern lakes. University of Minnesota Press, Minneapolis, USA.

Mennill, D. J. 2014. Variation in the vocal behavior of common loons (Gavia immer): insights from landscape-level recordings. Waterbirds 37:26-36.

National Oceanic and Atmospheric Administration [NOAA]. 2016. National Centers for Environmental Information. Climate data online: data tools: 1981-2010 normals. <https://www.ncdc.noaa.gov/cdo-web/ datatools/normal>. Accessed 16 Jan 2017.

Nocera, J. T., and P. D. Taylor. 2000. Behavior of post-nest failure and nonbreeding common loons during the breeding season. Wilson Bulletin 112:532-534.

Piper, W. H., K. B. Tischler, and M. Klich. 1999. Territory acquisition in loons: the importance of take-over. Animal Behavior 59:385-394.

Radomski, P. J., K. Carlson, and K. Woizeschke. 2014. Common loon (Gavia immer) nesting habitat models for north-central Minnesota lakes. Waterbirds 37:102-117.

Reiser, M. H. 1988. Effects of regulated lake levels on the reproductive success, distribution and abundance of the aquatic bird community in
Voyageurs National Park, Minnesota. National Park Service Research/ Resource Management Report MWR-13, Omaha, Nebraska, USA.

Ruggles, A. K. 1994. Habitat selection by loons in southcentral Alaska. Hydrobiologia 279/280:421-430.

Strong, P. I. V., and J. A. Bissonette. 1989. Feeding and chick-rearing areas of common loons. Journal of Wildlife Management 53:72-76.

Thompson, S. A., and J. J. Price. 2006. Water clarity and diving behavior in wintering common loons. Waterbirds 29:169-175.

Travis, S. E., J. E. Marburger, S. K. Windels, and B. Kubátová. 2010. Hybridization dynamics of invasive cattail (Typhaceae) stands in the Western Great Lakes region of North America: a molecular analysis. Journal of Ecology 98:7-16.

Travis, S. E., J. E. Marburger, S. K. Windels, and B. Kubátová. 2011. Clonal structure of invasive cattail (Typhaceae) stands in the upper Midwest region of the US. Wetlands 31:221-228.

Tuchman, N. C., D. J. Larkin, P. Geddes, R. Wildova, K. Jankowski, and D. E. Goldberg. 2009. Patterns of environmental change associated with Typha $\times$ glauca invasion in a Great Lakes coastal wetland. Wetlands 29:964-975.

Vermeer, K. 1973. Some aspects of breeding and mortality of common loons in east-central Alberta. Canadian Field-Naturalist 87:403-408.

Windels, S. K., E. A. Beever, J. D. Paruk, A. R. Brinkman, J. E. Fox, C. C. MacNulty, D. C. Evers, L. S. Siegel, and D. C. Osborne. 2013. Effects of water-level management on nesting success of common loons. Journal of Wildlife Management 77:1626-1638.

Associate Editor: Koper. 